\title{
4. Who Owns the 'De-Aboriginalised' Past? Ethnography meets photography: a case study of Bundjalung Pentecostalism
}

\author{
Akiko Ono \\ National Museum of Ethnology, Japan
}

\section{Introduction}

Since its inception, photography has provided a resource for the recording of ethnographic data and photographic evidence has been used in the construction of anthropological information in complex ways (Edwards 1992). Much has been said about the asymmetrical power relations between the ethnographer's gaze and Indigenous peoples subjected to the production of ethnographic knowledge (for example, Clifford 1986; Marcus and Fischer 1986; Rosaldo 1993; Said 1978; Spivak 1988; for Aboriginal issues, see, Attwood and Arnold 1992; Beckett 1988). In this chapter, rather than engaging in interpreting photographic ways of seeing within anthropology, I show how Nicolas Peterson's work on photographs enlightened me as to the ethnographic richness of photography per se. ${ }^{1}$ I learned how photography can provide evidence of the historical particularities of the photographed practices in which the Aboriginal subjects participated and how they interacted with the gaze of the photographer/ ethnographer. Peterson's insights destabilised my monolithic perspective about photographs of Indigenous peoples and the issue of cultural appropriation of Indigenous cultures. I once regarded the photography of colonial encounters simply as evidence of power that always silenced the Indigenous 'other', but learned to see them as much more than signs of oppression.

To undertake anthropology in Aboriginal Australia is to engage in a space of colonial encounters. Mary Louise Pratt (1992), in calling this space the 'contact zone', emphasised the interactive and improvisational dimensions of colonial

\footnotetext{
1 Peterson has built up a collection of process-printed (that is, mass-produced) postcard images and handprinted images dating from 1900 to 1920 (that is, real photographic postcards), over 20 years, during which time he obtained a copy every time he saw a new image. He feels confident that he has seen two-thirds of the process-printed picture postcards from the period although it is harder to estimate how many hand-printed images were circulating (Peterson 2005: 25n.3). He had a collection of 528 process-printed postcards (Peterson 2005: 25) and 272 hand-printed photographs (p. 18) by 2005.
} 
encounters and argued that the relations among colonisers and colonised should be explored in terms of 'copresence, interaction, interlocking understandings and practices' (p. 7), although we should not forget they are formed within radically asymmetrical relations of power. Here ethnography meets photography in this case study. In this chapter, by giving a brief outline of Peterson's work on Aboriginal photography, I first discuss Peterson's insights into the power of the visual knowledge that is often underestimated and replaced by the dichotomised discourse of colonial gaze and Indigenous subjugation. Then, I attempt to integrate Peterson's insights with my own ethnography of an Aboriginal Christian community in rural New South Wales (for more about Aboriginal people in New South Wales, see Kwok, this volume). I focus on the discrepancies between the actual visual knowledge of old photographs and Aboriginal people's reactions to them. During my fieldwork, the term 'holy rollers' held the key for understanding different manifestations of Aboriginality in this region. Aboriginal Christians of a particular local group were provoked to mention this term when they looked at the photographs of the old church. Through this case study, I examine how photography and ethnography have become complexly linked as a basis for anthropological inquiry. Last, based on my findings and Peterson's insights into the power of visual knowledge, I discuss the possibilities of the interactive dimensions for producing ethnographic knowledge in which both the subjugated other and the anthropologist can engage in inter-subjective mutual practices.

\section{The Interactive Dimensions}

Peterson criticises the concept of 'welfare colonialism' used to describe a 'welfare-dependent' situation of Indigenous peoples (see Kwok, this volume, for more on welfare colonialism and Altman and Martin, this volume, on welfare in the Australian Aboriginal context). He argues that this concept lacks the insider perspective regarding many aspects of Indigenous social and cultural life that welfare payments enable (Peterson 1998, 1999). For example, without having to be involved in any conventional productive activity, Aboriginal welfare beneficiaries are able to pursue Indigenous agendas - 'from the social exchange of drinking and card playing, to identity reinforcing supplementary subsistence pursuits and participation in ceremonial life' (Peterson 1999: 853). It is too easy for anthropologists to end up simply emphasising power relations but, he argues, what is more important is to become aware of the interactive dimensions between Aboriginal and state power in the form of everyday life. In these dimensions, anthropologists should focus on the ways in which people organise and understand their daily lives (Peterson 1999: 859-60). 
In his study of Aboriginal photography, Peterson also looks at the dynamics of colonial power relations in which both European and Aboriginal subjects are constituted in and by their relations to each other. Peterson in the main writes about two different contexts of the usage of photography of Aboriginal people

1. popular usage of photographs, especially in the form of postcards in the early twentieth century (Peterson 1985, 2005)

2. anthropologists' ethnographic involvement with photography (Peterson 2003, 2006).

Regarding the first, Peterson depicts how the discourses of atypical (that is, disorganised) family structures and destitution among Aboriginal people were produced and interacted with the prevalent moral discourses of the time. He makes an important remark about the interactive dimensions that existed between the photographer and the Aboriginal subject. Hand-printed postcards in the same period showed much more positive images of Aboriginal people (Peterson 2005: 18-22). These were 'real' photographs taken by the photographers who had daily interactions with Aboriginal people. Images such as those of people wearing better dresses, occupying better dwellings and undertaking Christian marriages were proclaiming the discourse of redemption, not destitution. Regardless of the presence of moral expectations from the photographer and the viewer, these photographs, taken in the midst of everyday interactions and colonial encounters, challenged the images of promiscuous Aboriginal women, of disorganised family structures and of sheer poverty that were prevalent in the mass-produced postcards of the period.

Peterson gives greater attention to photographs taken by anthropologists for scientific purposes, and in this second context provides a more detailed treatment of his insight regarding the discrepancies between the colonisers' discourse and the actual visual knowledge that photography offers. Commenting on the lavishly photographed ethnography The Native Tribes of Central Australia by Spencer and Gillen (1899), Peterson (2006) points out the quality of the evidence of Arrernte ceremonial performances available from the 119 photographs. They demonstrate the complexity and sophistication of Arrernte religion and challenge the conventional understandings of Arrernte people derived from the authors' own evolutionary assumptions, providing a visual counter-narrative to the overt orientation of the text.

These two contexts are not, of course, mutually exclusive. By dealing with image ethics and the changing photographic contract, Peterson (2003) shows the interlocking formations of popular image, anthropological knowledge and Aboriginal self-representation. In particular, it is important to remember that Aboriginal people have not always rejected collaboration with and appropriation of the idioms of the coloniser. Aboriginal people were not bothered by posing for 
photographers to produce images such as 'naked' Aboriginal men and women in formal pose, accompanied by an 'unlikely combination' of weapons (Peterson 2005); and at times complex negotiations occurred between the photographer and the photographed-resulting in both consent and refusal (Peterson 2003: 123-31).

These anecdotes suggest the necessity of unravelling the 'lived' dimensions of colonial and/or racial subjugation and resistance to that subjugation from the site of their occurrence. Inspired by Peterson's insights, in what follows, I explore Aboriginal agency and the power of visual knowledge shown in the photographs from my own field site among Aboriginal Christians in northern New South Wales, Australia. Photography, ethnography, memory and tradition are linked in complex ways, demonstrating the value of photography as a basis for anthropological inquiry.

\section{The Pentecostals and the Dissidents}

North Coast Aboriginal Christianity is well known to Australian anthropologists through the work of Malcolm Calley, who researched the Aboriginal Pentecostal movement that broke out in the middle of the twentieth century on the far North Coast of New South Wales (Calley 1955, 1959, 1964). He represented the studied group as 'Bandjalang', which actually covered several linguistic groups, and a version of this name, 'Bundjalung', is still used as a political unit, referring to all except one group living in the area. Calley's work gives a vivid impression to readers of the vivacity of this mid-century movement, and although the zeal of the revival is ebbing and Christians are in a small minority, ${ }^{2}$ the energy of that movement is palpable even today in the legacy of Pentecostal Christianity prevailing among North Coast Aboriginal Christians.

Calley depicts the Bundjalung people's Pentecostal movement in the mid-1950s as 'syncretic' and 'doctrinally too unorthodox to fit easily into one of the white pentecostal organizations' (Calley 1964: 57). He emphasised the 'mystic' and 'ecstatic' aspects of the Bundjalung Pentecostals and demonstrated the church's 'unorthodox' or indigenised features. The ritual practices such as 'speaking in tongues' (that is, glossolalia) and 'baptism with the Holy Spirit' (that is, spirit in-filling) — which were universal Pentecostal phenomena - were interpreted by Calley merely as fanaticism and/or the re-emergence of traditional Aboriginal beliefs and practices.

2 The term 'revival' means a new awakening of spiritual awareness and growth of faith in God, not the revitalisation of any former religious movements. 
During my fieldwork in the region between 2002 and 2004, I carried old photographs taken by Calley and others of this period. They were images of church buildings, open-air venues, services at large-scale conventions, local leaders and congregations taken in the mid-1950s. The photographs seemed to represent fully 'de-Aboriginalised' church meetings and religious practices undertaken by people typical of the Aboriginal peoples of mixed descent in south-eastern Australia. The Europeanisation of lifestyle and loss of traditional material culture are obvious in these images. Importantly, Aboriginal adherents in the photographs were all well dressed and the services were being conducted in an orderly way (see Figures 4.1 and 4.2). The organisers and helpers seem to be committed to pursuing well-planned procedures in order to host a big convention catering to approximately 200-500 Aboriginal visitors (Calley 1959: 219-22, 232-8) (see Figures 4.3, 4.4, 4.5). In much the same manner as the previous contrast noted in Spencer and Gillen, these photographs seem to contradict the apparently fanatical aspects of what Calley (1964: 57) identified as religious groups on the 'lunatic fringe'.

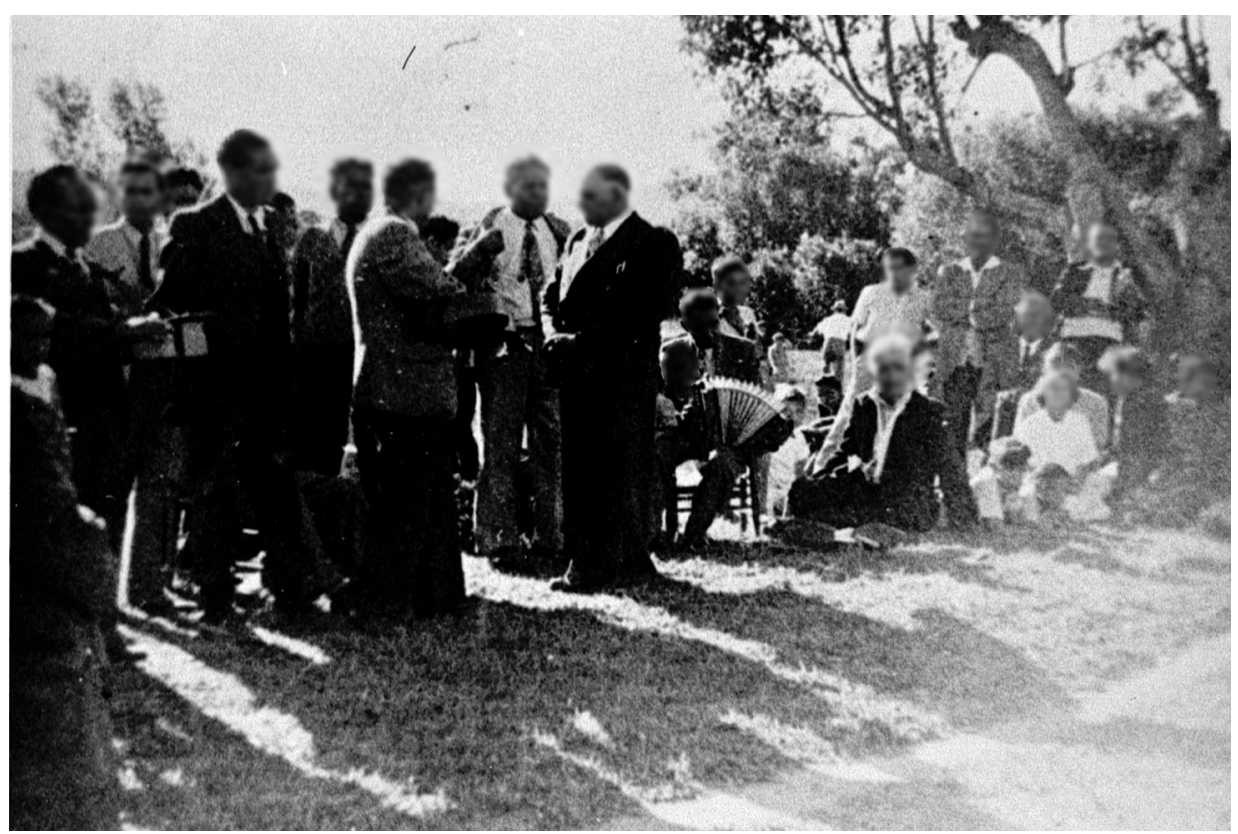

Figure 4.1 Open-air meeting at Cabbage Tree Island, ca. 1955

Image courtesy of Australian Institute of Aboriginal and Torres Strait Islander Studies, Chris Sullivan collection (Sullivan.C4.BW-N4520.07). 


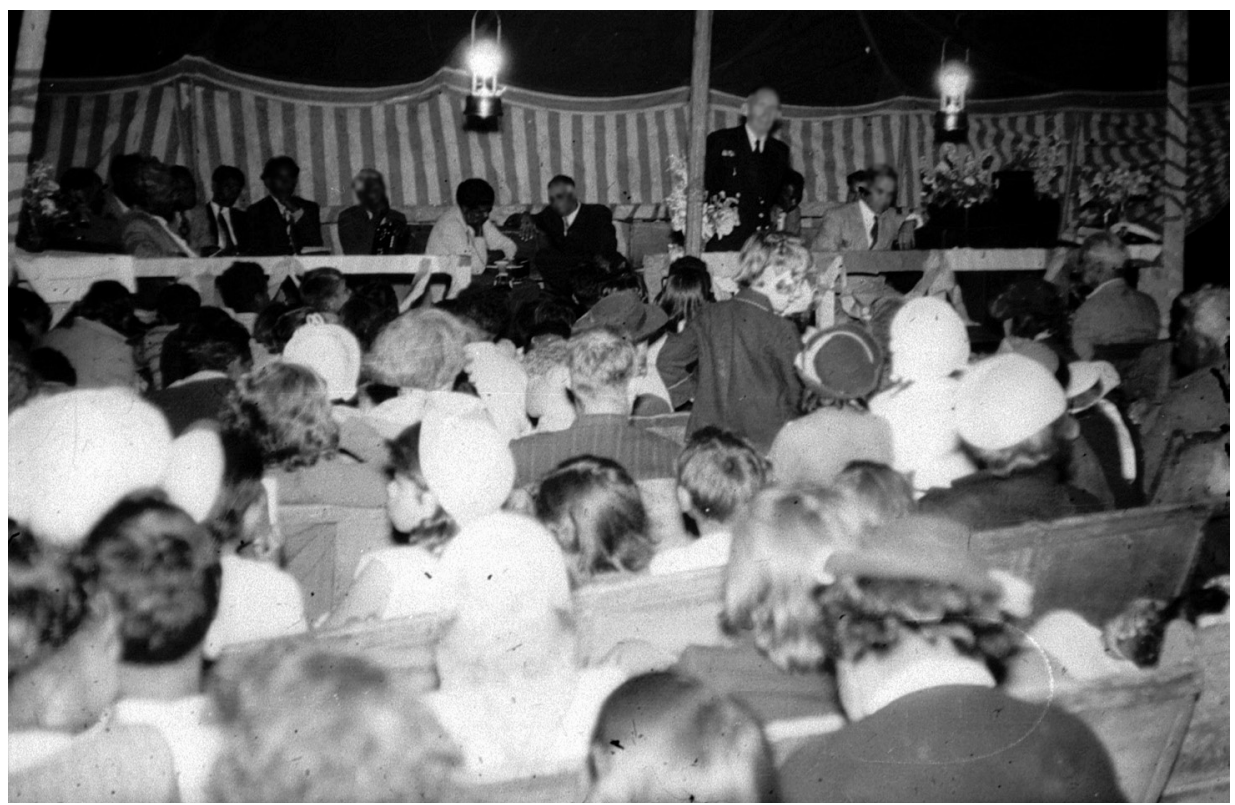

Figure 4.2 Night service at the Tabulam convention, 1955

Image courtesy of Australian Institute of Aboriginal and Torres Strait Islander Studies, Laila Haglund collection, photograph by Malcolm Calley (Haglund.L2.BW N4835.09).

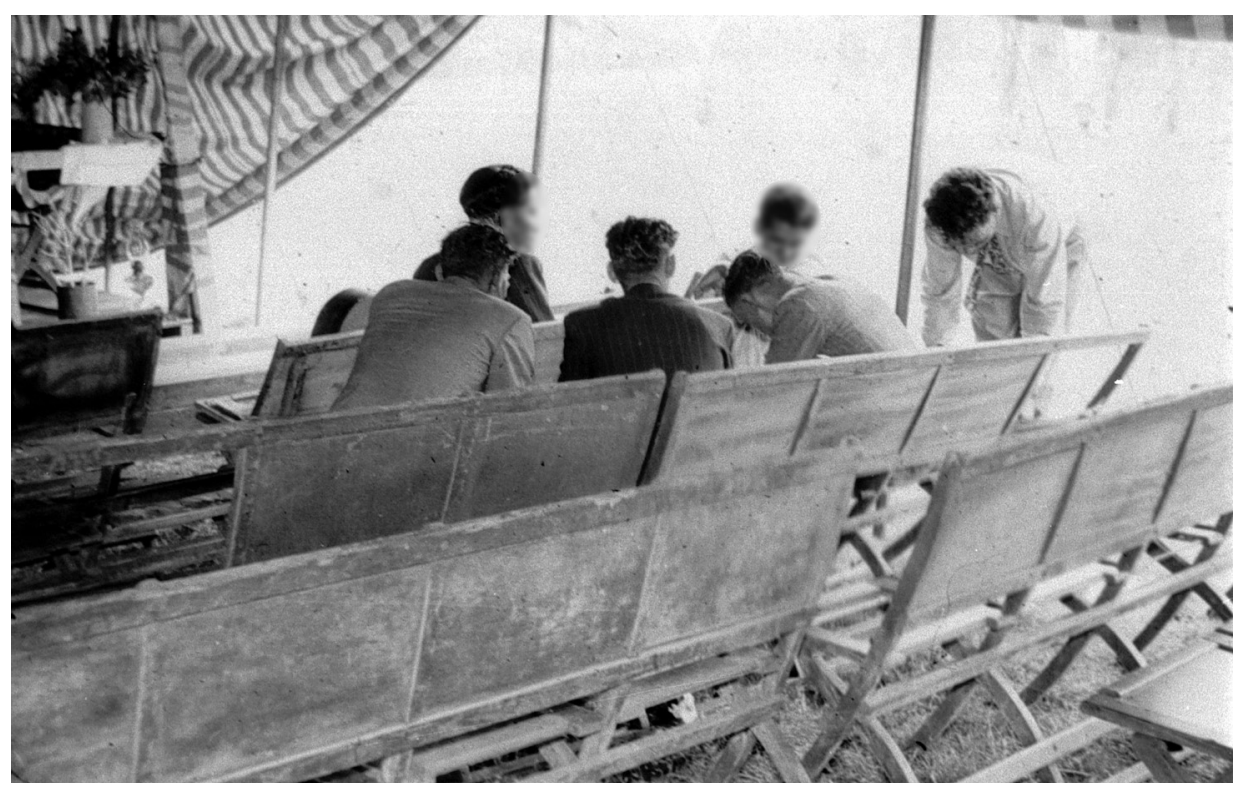

Figure 4.3 Organisers of the Tabulam convention, 1955

Image courtesy of Australian Institute of Aboriginal and Torres Strait Islander Studies, Laila Haglund collection, photograph by Malcolm Calley (Haglund.L2.BW N4835.08). 


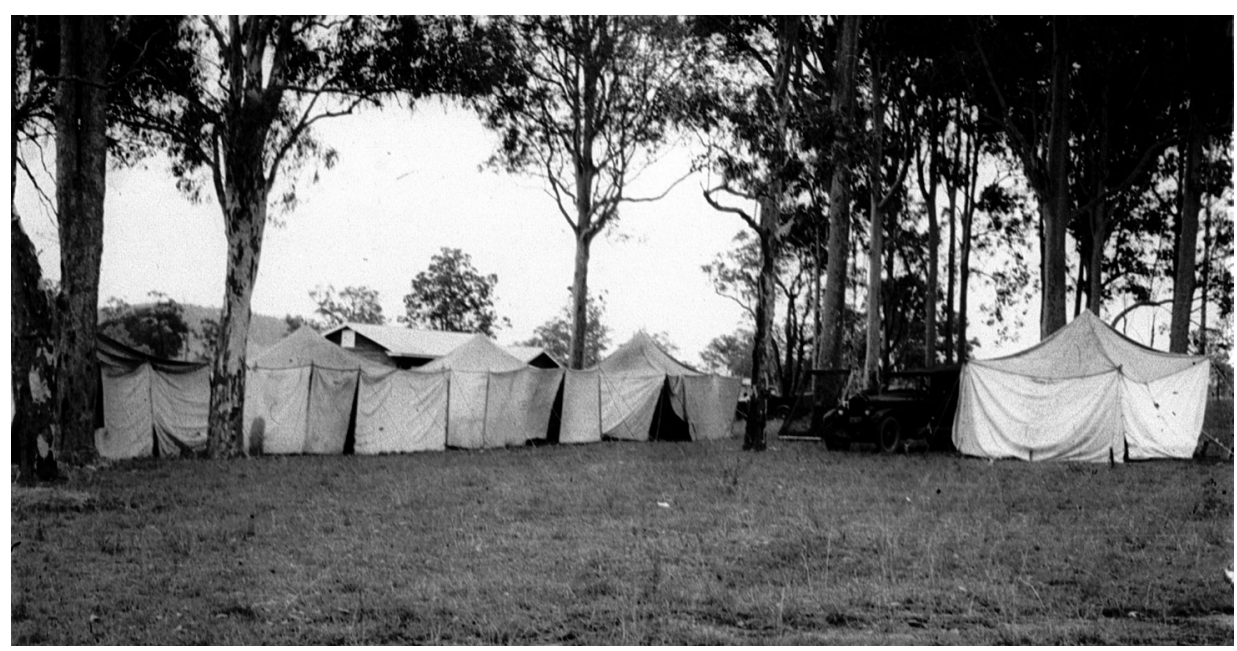

Figure 4.4 Tents hired to accommodate visitors to the Tabulam convention, 1955

Image courtesy of Australian Institute of Aboriginal and Torres Strait Islander Studies, Laila Haglund collection, photograph by Malcolm Calley (Haglund.L2.BW N4836.20).

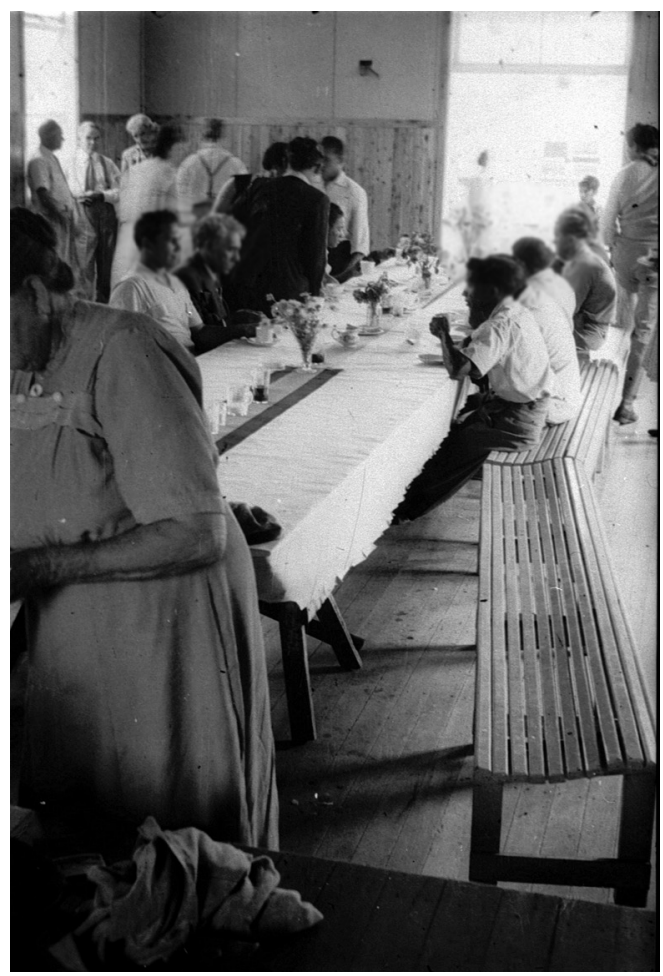

Figure 4.5 Meal break at a hall at the Tabulam convention, 1955

Image courtesy of Australian Institute of Aboriginal and Torres Strait Islander Studies, Laila Haglund collection, photograph by Malcolm Calley (Haglund.L2.BW N4835.11). 
Obviously, there are discrepancies between the actual visual knowledge that these photographs provide and the interpretation in Calley's ethnography. I attribute this to the particular academic bias in favour of continuity of traditionality regarding the studies of mixed-descent Aboriginal communities. The study of Aboriginal Christianity has also been bound predominantly by this conceptual framework of persistence and change. Until the 1970s and 1980s, Aboriginal Christianity was regarded as peripheral to mainstream anthropological study (cf. Rose and Swain 1988). As the focus of Aboriginal anthropology shifted from the salvage approach to observing change, the analytical focus on Aboriginal Christianity changed accordingly and was fixed on the tension between Aboriginal and exogenous socio-cultural orders - in the context of either incommensurable divisions between Christian practice and Aboriginal cosmology (Kolig 1981; Rose 1988; Tonkinson 1974; Trigger 1988) or synthesising the processes of the two religions (McDonald 2001; Magowan 1999, 2001). Conceptually, the dichotomised framework of persistence and change is posited in these positions in the form of the binary opposition of resisting Aboriginal culture (which is represented as somewhat a totality of meanings despite minor changes) and invading European knowledge.

According to Terence Ranger (2003: 258), the Australianist approach to Aboriginal Christianity, until recently, has been preoccupied with unchanging continuity and/or 'the contrast with the excitements of Oceanic Christianity'. As Ranger (2003: 257) eloquently puts it, the 'shadowy play of unmodified tradition' has long attracted ethnographers' attention rather than the 'real stuff of dynamic interaction' (p. 258) (see also Merlan 1998: 151). Carolyn Schwarz and Françoise Dussart (2010) aptly address this agenda and argue that the persistence of Aboriginal kin relatedness is one of the reasons Australian studies of Christianity have been omitted from generalist discussions. Because the principles of kin relatedness have powerfully governed religious affiliations as well as other social practices, this situation has distracted Australianists' interest in the dynamics of the changing moral order that Aboriginal people themselves would accept on its own terms. Even if it is Aboriginal peoples' own self-representation, the 'shadowy play of unmodified tradition' begs re-examination. In a similar vein, Diane Austin-Broos (2010: 15) argues that processes of rupture and continuity are mutually inclusive. Some recent studies of Aboriginal Christianity examine the particularity of the local contact processes in which vernacular Christianity has been formed as such (Austin-Broos 2003, 2010; Brock 2003; Myers 2010; Trigger and Asche 2010; Van Gent 2003). In what follows, I attempt to add strength to this perspective by providing a case study of my own.

The Bundjalung population today is widely dispersed in the far northern coastal region of New South Wales, and the Christian community cuts across several settlements, including ex-station and reserve settlements, fringe towns and 
urban centres. According to the 2001 Census, the Aboriginal population of this area is approximately 6000, making up about 3 per cent of the total population. As my fieldwork developed, I started showing these photographs from the archives to people, as so many seemed keen on looking at photographs of their kin and the legendary lay pastors they had heard of or lived with in the past. There was, however, one striking exception to this situation in a small coastal community inhabited by non-Pentecostal Bundjalung Christians. Aboriginal Christians of this coastal community had a drastically different response to the photographs of the old Bundjalung churches from that of the Pentecostals in the inland communities. This community, which I will call the 'coast village', has an Aboriginal population of approximately 370 and, like most other Bundjalung communities, it has an independent Aboriginal church. But uniquely in the region, it does not identify itself with the Pentecostal or charismatic movements.

\section{The Enigma of the 'Holy Rollers'}

When looking at my photographs, the inland people who have maintained a Pentecostal legacy readily acknowledged the well-organised conventions and perfectly groomed men and women in the photographs - for example, men in suits and women in long skirts and hats, tents hired for guests, adherents neatly seated for communion, and so on. In contrast with this, in the coast village noone, including members of the older generation, seemed familiar with the people and the meetings. Ultimately, a church leader's wife made her point of view known as such: 'These [photographs] can't be from their [inland Pentecostals'] church!' She did not want to accept that the photographed meetings were of the inland people whom they had long imagined to be fanatical 'holy rollers'.

Thus, the memory of 'holy rollers' suddenly sprang into ethnography from the photographic evidence. 'Holy roller' is a term used to describe Pentecostal worshippers and is generally considered pejorative. It describes people literally rolling on the floor or, more generally, describes Pentecostal Christians' emotional behaviour when they receive baptism with the Holy Spirit. It is highly probable that the memory of the 'holy rollers' was the source of the aversion towards Pentecostalism in the coast village. The church leader's wife told me she had heard about the 'Pentecostal' meetings that had come to the coast village and associated with the local residents - though for a short duration. Adherents used to go to the beach for meetings and rolled across the sand endlessly - every day, over and over again. An older leader of the coast village's church testified that he had heard about the 'holy rollers' meetings' in his father's time: 'there were meetings held at night; and people were rolling on the floor... when a man and a woman reached the edge of the venue, they stood up and went out into the bush.' 
Strangely enough, the inland Bundjalung Pentecostals did not share the memory of the 'holy rollers', nor did they know what the term exactly meant. No-one recollected rolling across the floor of the venue during the service nor had anyone even heard of such a practice among themselves. Of course, this term had spread to the general public during the period of the Bundjalung Pentecostal revival to describe Pentecostal Christian churchgoers. A retired white missionary and his wife from the local town confirmed this at my interview. Unless the term 'holy roller' had been associated with everyday practice, the local Aboriginal Pentecostals would have had no idea what it meant. Arguably, such a worship style - loathed by the majority of the coast village - never existed among the inland Bundjalung Pentecostals.

Today, the Bundjalung Pentecostals usually receive the Holy Spirit in such forms as 'getting slain' in the Spirit, speaking in tongues and faith healing. These manifestations - often depicted as emotional or ecstatic by observerswere rather different from shamanistic activities such as spirit possession and the trance séance. Mircea Eliade (1988: 4-5) underlines a 'technique of ecstasy' in his concept of original, pure shamanism, whereas specific socio-cultural elements and relational or intermediary roles have more weight in most forms of shamanism - such predominantly theatrical practices as healing, ordeals and consultation between the shaman and the petitioner (Lewis 1986). The most appropriate expression, however, for my Aboriginal informants' 'spirit-filled' experiences is neither ecstatic (or emotional) nor theatrical (or relational), even though lay witnesses would assert that they are. Rather, I would depict their experiences as intellectual. Many of them regarded the occasion as a divine trial or the like. When getting 'slain' in the Spirit, the person lies still on the ground but he or she retains consciousness and abides with the feeling of God's presence. In many cases, their faith was to be challenged through this experience. When receiving the Holy Spirit, people are totally indifferent to the relational aspect of such seemingly theatrical practices. For that reason, baptism with the Holy Spirit is an exclusively personal experience; and it could happen anywhere - even in the privacy of one's own home.

A Christian man told me about how he was given a new direction 'in Him' through baptism with the Holy Spirit. This man was in his late thirties and had recently gone through difficulties, including the death of his father, heartbreak by a white girlfriend and the loss of a full-time job after 10 years of employment. One Sunday close to Christmas, he was at home alone, as his sisters had gone to church. He got up about $9.30 \mathrm{am}$. He went into the kitchen to have breakfast. All of a sudden, he was 'spirit-filled'; he started talking in tongues, which lasted for at least 20 minutes. He was conscious and his state of mind was clear and calm. In the kitchen, during the long presence of God, he was convinced that he had become reconciled with God just as he was about to turn away from Him: 
The Lord has really changed me from what person I was before, and it was then that I was not living right for the Lord...I used to love Gospel Pop songs, I had an attitude towards my family, I was also into a lot of wrong stuff that you would not believe. I was worldly...I was hanging around the wrong crowd; and the love song I wrote about Claire [his ex-girlfriend] was going to be a hit song in the music industry. Yes, that is where I was heading. A guy in Byron Bay who has worked with a lot of famous singers as a producer of their albums heard my love song and was very impressed. I was heading towards, I guess, to fame and maybe fortune. But in that period God was dealing with me and convincing me not to go the way of the world and that I must repent and turn to Him although it was my choice. But, in the end, I surrendered to God and got reconverted. I now have the witness of the Spirit of God in me, amen! Since then I have never been the same again. God has given me a new direction in Him. So, after I surrendered my life back to God, I told the guy from Byron Bay I was not going to have no part in rerecording... and no part in becoming famous. The Lord has also changed my attitude towards my family and all people;

I just have love for my family and people!

The way of experiencing the outpouring of the Holy Spirit varies according to each individual. Some people did mention the emotion-oriented aspects of this phenomenon to me. Some said it was like being struck by electricity; some said they just felt warmth; some lay still and saw visions. I occasionally even saw a few people who started crying - or laughing. But as the testimony highlights, the term 'ecstasy' is an inappropriate expression for the way the inland Bundjalung Pentecostals abide in the presence of God.

\section{The Owner of the 'De-Aboriginalised' Past}

Later research uncovered the past presence of two different strongly sectarian movements based on the farthest coastal area of the Bundjalung country, which included the coast village. First, in the 1920s there was a group of 'Americans' who held notorious meetings of 'holy rollers' in the village, but about whom little else is known or remembered. An older leader recollected that it was said to have died out in about 12 months. The second movement lasted longer, beginning in 1947 when Douglas Pinch, an itinerant missionary of the Church of the Nazarene, moved into the coast village with his family and associated with some of the Aboriginal Christians 
(O'Brien 2003, 2008). ${ }^{3}$ These white Pentecostals imprinted a marked aversion to the 'spirit-filled' way of worship of Pentecostal and charismatic churches on the minds of the coast villagers. ${ }^{4}$

The inland congregations sprang from a different root than that of the coast village. Despite the presence of the United Aborigines Mission (UAM), ${ }^{5}$ which presumably intensified from the 1930s till the 1950s, the Aboriginal people in inland communities accepted Pentecostal Christianity before the arrival of the UAM missionaries under a diverse Aboriginal lay leadership as early as the 1910s or 1920s. Since then the Aboriginal Christian community has been functioning as one organic body (Ono 2007: Ch. 2).

On the other hand, the coast village's church has grown from the Aboriginal Inland Mission (AIM), because the settlement itself was established by the AIM. In the 1970s, the AIM left the community and the church is now an independent Aboriginal church. ${ }^{6}$ It distinctly draws a line between itself and the Pentecostal doctrine and worship style. The church pastor and lay leaders do not agree with the gifts of baptism by the Holy Spirit, speaking in tongues and faith healing. To the coast villagers, such a neatly 'de-Aboriginalised' past of the inland Pentecostals shown in the old photographs did not fit with their idea of Pentecostals in the inland communities. I would suggest there are two main reasons for this.

First, the very well organised meetings attended by well-dressed black men and women in the 1950s contradicted the coast villagers' negative conceptions of the inland Bundjalung communities, and also of the Pentecostal worship style. In other words, the image of fanatic 'holy rollers' easily fitted into their representation of the poor and less-civilised quarters in the hinterland. It is evident that coast village Aboriginal people are, in general, better off and more thoroughly integrated into wider Australian society than those in the

3 As a historian, $\mathrm{O}^{\prime}$ Brien concludes, based on the history and ethnographies written from the white viewpoint, including Pinch's own memoir (Pinch n.d.), that the 'Bandjalang people, already marginalized from both white Australian society and other Aboriginal groups, proved very open to the Nazarene message' (O'Brien 2003: 228). But the pastor of the coast village who was Pinch's contemporary flatly denies it, although it is well known that the inland Pentecostals welcomed - and still welcome - any white preachers, Pentecostal or not, to their conventions.

4 O'Brien $(2003,2008)$ reached a different conclusion, which reflects elaborate and exemplary historical research, but the Aboriginal people's remarkably different point of view is doomed to exclusion by this and most other historical research.

5 The UAM was the main force that evangelised the Aboriginal people in New South Wales (Telfer 1939; UAM 1994). The UAM missionaries had been visiting the far North Coast Aboriginal communities sporadically from other bases since the early 1900s but it was in 1937 when a church was erected in one of the inland superintendent stations to serve as a centre to evangelise the farthest northern coastal region (cf. The United Aborigines' Messenger 1929-59). There are abundant narrative recollections that the Aboriginal people had already started their own meetings in the inland communities under their own lay leaders about the turn of the century.

6 The church has sought affiliation with the Aboriginal Evangelical Fellowship of Australia (AEF) (<http:// www.aef.org.au/> viewed 18 August 2009). 
inland communities - mainly because of the history of migrant industry and the consequent multi-ethnic social environment of the region (cf. Cane 1989). Difference of lifestyle from the rest of the inland Aboriginal community is evident in the farthest north of the Bundjalung country: better housing, better education, better employment, greater multi-ethnic (especially, Pacific islander) population and, consequently, less kin relationships with other Christian congregations of the Bundjalung Pentecostal network. Due to its multi-ethnic background, Aboriginal sociality is not constituted on kin relationships (which could be tracked down through the inland communities), but relies on the political economy of Aboriginal administrative and institutional policies.

Second, the congregation of the old days that looked 'just like a white church' as indeed the church leader's wife commented - did not appeal much to the coast village Christians as an Aboriginal church. The coast village identifies itself strongly as being Aboriginal and the people there are keen on demonstrating traditional culture. Notwithstanding its social and economic deviation from the local Aboriginal standard and emotional detachment from kin relationships within the Bundjalung community, the coast village identifies itself as part of a political unit of the 'Bundjalung nation'. Those who are in fact of multi-ethnic descent cherish political discourses of Aboriginality and show much interest in contemporary Aboriginal politics and cultural revitalisation.

In a similar vein, its church is keen on representing Aboriginality. The Christians are willing to take part in public cultural events and maintain an Aboriginal niche' in mainstream society. For example, the church leader's children have formed an Aboriginal dance group to make a living. These Christian traditional dancers are willing to perform regardless of contexts - whether a Christian convention or a National Aboriginal and Islander Day Observance Committee (NAIDOC) cultural festival. Naked bodies, ochre paintings, loincloths and grass skirts are prerequisites for such performances.

In the inland communities, the most frequently heard narrative is 'We had our own [that is, Aboriginal] church from the beginning'. This discourse suggests the existence of consistent Aboriginal leadership throughout the process of their Christianisation (see, for example, Figure 4.3). Those who have maintained Aboriginal control over the process of Christianisation are not concerned about the 'de-Aboriginalised' features of their past and, correspondingly, of the present. That is, any essentialistic discourse of traditional past is unnecessary for those who have, despite drastic social change, a strong sense of continuity in everyday practice in the Aboriginal social domain, hence making them resistant to the colonial gaze. In other words, the Bundjalung Pentecostals do not find it necessary to reject the colonisers' idiom while they are embracing the benefits of 
the exogenous religion. As Taussig (1993: 129) says of a different ethnographic context, the issue is 'not so much staying the same, but maintaining sameness through alterity'.

Taussig (1993: xiii) argues for a notion of mimesis as a kind of mirroring relationship between the coloniser and the colonised, where the 'mimetic faculty' is 'the nature that culture uses to create second nature, the faculty to copy, imitate, make models, explore difference, yield into and become Other'. Furthermore, Taussig (1993: 2) attends to the 'magical, soulful power that derives from replication', which can have a function that could break the closed circle of mimesis and alterity. Interestingly, Bundjalung Pentecostalism neither entails the pursuit of modern individualism and consequent detachment from loyalty to kin relationships nor prompts adherents to cultivate social orientation and ethical self-formation towards the mainstream (European) values. Far from 'becoming like whites' through embracing the colonisers' idiom, the Pentecostal Bundjalung are ultimately led to reinforce social and emotional relatedness to one another and maintain Aboriginal sociality within their community (Ono 2008).

On the other hand, those who lack a substantial Aboriginal domain in their life worlds can cultivate only an abstract image of the traditional past. The coastal anti-Pentecostals have recurrently reproduced the white gaze in their recognition of Aboriginality; the image of the howling savage fanatically rolling across the beach readily fitted into their representation of the poor and lesscivilised sections of their own people.

\section{Conclusion: The power of 'autoethnography'}

I have shown how the complex relationships between photography and ethnography that emerged during my fieldwork have had important analytical implications. The old photographs of Aboriginal Christians, which appeared to merely represent mimicry of white Christianity, have in the end revealed what the authenticity of Aboriginality is about. Undoubtedly, the inland Bundjalung Pentecostals are the owners of the 'de-Aboriginalised' past. I have argued that it does not necessarily mean they have reproduced the colonisers' values to undermine their own; nor do the more culturally conscious coast village Christians produce authentic or autochthonous forms of self-representation. Rather than scrutinising the authenticity of Aboriginality or taking it for granted that ethnographic photography is doomed to reproduce a colonial or anthropological power structure, it is more important to attend to the instances in which colonized subjects undertake to represent themselves in ways that engage with the colonizer's own terms', as Pratt (1992: 7, emphasis in the original) 
suggests. She proposes the term 'autoethnography' to refer to these instances: 'If ethnographic texts are a means by which Europeans represent to themselves their (usually subjugated) others, autoethnographic texts are those the others construct in response to or in dialogue with those metropolitan representations' (Pratt 1992). There is, no doubt, a need for anthropological endeavours to explore the power of autoethnography that both the subjugated other and the conqueror can engage in.

In Predicament of Culture, James Clifford (2002: 277-346) discusses a Native American land claim situation not unlike those engaged in by Aboriginal people. He examines the contest between oral and literate forms of knowledge and the role that notions of cultural continuity (cf. Trigger 2004) play in preserving this dichotomy. In the Mashpee claim he analyses, 'the court's common sense was that the plaintiffs' identity must be demonstrated as an unbroken narrative, whether of survival or change' (Clifford 2002: 341). The requirement was for 'a historian's seamless monologue' (Clifford 2002: 340), but 'oral societies - or more accurately oral domains within a dominant literacy-leave only sporadic and misleading traces. Most of what is central to their existence is never written' (p. 341).

The anthropologist's inter-subjective practice of fieldwork and ethnography can articulate the oral and the literate with each other. It can also bring autoethnographic texts to light. Ethnographic photography is part of the literate world represented by the outsider, but as I have explored in this case study, owing to its overpowering visual knowledge, photography carries the potential to be turned into autoethnography of the native - just like that manifested in Spencer and Gillen's The Native Tribes of Central Australia (1899), as argued by Peterson (2006). When situated in the inter-subjective mutual practice with the ethnographer/photographer/fieldworker, through the colonisers' idioms, the Native can gaze back from the images, the production of which they once let others control.

\section{References}

Attwood, B. and J. Arnold (eds), 1992. Power, Knowledge and Aborigines. Bundoora, Vic.: La Trobe University Press in association with the National Centre for Australian Studies, Monash University.

Austin-Broos, D. J. 2003. The meaning of Pepe: God's law and the Western Arrernte. The Journal of Religious History 27 (3): 311-28.

Austin-Broos, D. J. 2010. Translating Christianity: some keywords, events and sites in Western Arrernte conversion. The Australian Journal of Anthropology 21 (1): 14-32. 
Beckett, J. 1988. The past in the present: the present in the past: constructing a national Aboriginality. In J. R. Beckett (ed.) Past and Present: The Construction of Aboriginality, pp. 191-217. Canberra: Aboriginal Studies Press for the Australian Institute of Aboriginal Studies.

Brock, P. 2003. Two indigenous evangelists: Moses Tjalkabota and Arthur Wellington Clah. Journal of Religious History 27 (3): 348-66.

Calley, M. J. C. 1955. Aboriginal Pentecostalism: A Study of Changes in Religion, North Coast, NSW. MA Thesis, University of Sydney, NSW.

Calley, M. J. C. 1959. Bandjalang Social Organisation. PhD Thesis, University of Sydney, NSW.

Calley, M. J. C. 1964. Pentecostalism among the Bandjalang. In M. Reay (ed.) Aborigines Now, pp.48-58. Sydney: Angus and Robertson.

Cane, S. 1989. Welcome to Fingal: Aboriginal associations with Fingal Head, NSW. A report to Ocean Blue Pty Ltd.

Clifford, J. (ed.) 1986. Writing Culture: The Poetics and Politics of Ethnography. Berkeley: University of California Press.

Clifford, J. (ed.) 2002 [1988]. Predicament of Culture: Twentieth-Century Ethnography, Literature, and Art. Cambridge, Mass., and London, UK: Harvard University Press.

Edwards, E. (ed.) 1992. Anthropology and Photography 1860-1920. New Haven, Conn.: Yale University Press.

Eliade, M. 1988. Shamanism: Archaic Techniques of Ecstasy. London: Arkana, Penguin.

Kolig, E. 1981. The Silent Revolution: The Effects of Modernization on Australian Aboriginal Religion. Philadelphia: Institute of the Study of Human Issues.

Lewis, I. M. 1986. Ecstatic Religion: A Study of Shamanism and Spirit Possession. London and New York: Routledge.

McDonald, H. 2001. Blood, Bones and Spirit: Aboriginal Christianity in an East Kimberley Town. Carlton South, Vic.: Melbourne University Press.

Magowan, F. 1999. The joy of mourning: resacralising 'the sacred' in the music of Yolngu Christianity and an Aboriginal theology. Anthropological Forum 9 (1): 11-36.

Magowan, F. 2001. Syncretism or synchronicity? Remapping the Yolngu feel of place. Beyond syncretism: indigenous expressions of world religions. The Australian Journal of Anthropology 12 (3): 275-90.

Marcus, G. E. and M. J. Fischer, 1986. Anthropology as Cultural Critique: An Experimental Moment in the Human Sciences. Chicago: University of Chicago Press. 
Merlan, F. 1998. Caging the Rainbow: Places, Politics, and Aborigines in a North Australian Town. Honolulu: University Of Hawai'i Press.

Myers, F. 2010. All around Australia and overseas: Christianity and indigenous identities in central Australia 1988. The Australian Journal of Anthropology 21: 110-28.

O'Brien, G. 2003. 'A dogged inch-by-inch affair': the Church of the Nazarene in Australia 1945-1958. Journal of Religious History 27 (2): 215-33.

O'Brien, G. 2008. Doug and Maysie Pinch and the Nazarene mission to the Bandjalang. Australian Journal of Mission Studies 2 (2): 45-52.

Ono, A. 2007. Pentecostalism Among the Bundjalung Revisited: The Rejection of Culture by Aboriginal Christians in Northern New South Wales, Australia. PhD Thesis, The Australian National University, Canberra.

Ono, A. 2008. The meaning of 'culture' among Aboriginal Pentecostal Christians: doing anthropology of discontinuity in Australia. Japanese Review of Cultural Anthropology 9: 29-51.

Peterson, N. 1985. The popular image. In I. Donaldson and T. J. Donaldson (eds), Seeing the First Australians, pp. 164-80. Sydney: Allen \& Unwin.

Peterson, N. 1998. Welfare colonialism and citizenship: politics, economics and agency. In N. Peterson and W. Sanders (eds), Citizenship and Indigenous Australians: Changing Conceptions and Possibilities, pp. 101-17. Cambridge: Cambridge University Press.

Peterson, N. 1999. Hunter-gatherers in first world nation states: bringing anthropology home. Bulletin of the National Museum of Ethnology 23 (4): 847-61.

Peterson, N. 2003. The changing photographic contract: Aborigines and image ethics. In C. Pinney and N. Peterson (eds), Photography's Other Histories, pp. 119-45. Durham, NC: Duke University Press.

Peterson, N. 2005. Early 20th century photography of Australian Aboriginal families: illustration or evidence? Visual Anthropology Review 21 (1-2): 11-26.

Peterson, N. 2006. Visual knowledge: Spencer and Gillen's use of photography in The Native Tribes of Central Australia. Australian Aboriginal Studies (1): 12-22.

Pinch, D. W. n.d. [2009]. In the beginning: the Church of the Nazarene, Australia 1945-48. Unpublished memoir.

Pratt, M. L. 1992. Imperial Eyes: Travel Writings and Transculturation. London: Routledge.

Ranger, T. 2003. Christianity and indigenous peoples: a personal overview. Journal of Religious History 27 (3): 255-71.

Rosaldo, R. 1993. Culture and Truth: The Remaking of Social Analysis. Boston: Beacon Press. 
Rose, D. B. 1988. Jesus and the dingo. In D. B. Rose and T. Swain (eds), Aboriginal Australians and Christian Missions: Ethnographic and Historical Studies, pp. 361-75. Bedford Park, SA: Australian Association for the Study of Religions.

Rose, D. B. and T. Swain, 1988. Introduction. In D. B. Rose and T. Swain(eds), Aboriginal Australians and Christian Missions: Ethnographic and Historical Studies, pp. 1-8. Bedford Park, SA: Australian Association for the Study of Religions.

Said, E. W. 1978. Orientalism. New York: Pantheon Books.

Schwartz, C. and F. Dussart, 2010. Christianity in Aboriginal Australia revisited. The Australian Journal of Anthropology 21 (1): 1-13.

Spencer, B. and F. J. Gillen, 1899. The Native Tribes of Central Australia. London: Macmillan.

Spivak, G. C. 1988. Can the subaltern speak? In C. Nelson and L. Grossberg (eds), Marxism and the Interpretation of Culture, pp. 271-313. Urbana: University of Illinois Press.

Taussig, M. 1993. Mimesis and Alterity: A Particular History of the Senses. New York: Routledge.

Telfer, E. J. 1939. Amongst Australian Aborigines: Forty Years of Missionary Work, the Story of the United Aborigines Mission. Sydney: Fraser \& Morphet.

Tonkinson, R. 1974. The Jigalong Mob: Aboriginal Victors of the Desert Crusade. Menlo Park, Calif.: Cummings.

Trigger, D. S. 1988. Christianity, domination and resistance in colonial social relations: the case of Doomadgee, northwest Queensland. In T. Swain and D. B. Rose (eds), Aboriginal Australians and Christian Missions: Ethnographic and Historical Studies, pp. 213-35. Bedford Park, SA: The Australian Association for the Study of Religions.

Trigger, D. S. 2004. Anthropology in native title court cases: 'mere pleading, expert opinion or hearsay'? In S. Toussaint (ed.) Crossing Boundaries: Cultural, Legal, Historical and Practice Issues in Native Title, pp. 24-33. Carlton, Vic.: Melbourne University Press.

Trigger, D. S. and W. Asche, 2010. Christianity, cultural change and the negotiation of rights in land and sea. The Australian Journal of Anthropology 21 (1): 90-109.

United Aborigines Mission (UAM) 1994. Challenging the Almighty: 100 Years of Trusting God in the Work of the United Aborigines Mission. Box Hill, Vic.: United Aborigines Mission.

Van Gent, J. 2003. Changing concepts of embodiment and illness among the Western Arrernte at Hermannsburg mission. Journal of Religious History 27 (3): 329-47. 